\title{
DETERMINANTS OF DECISIONS TO ENTER THE U.S. FARMING SECTOR
}

\author{
ASHOK K. MISHRA* \\ Morrison School of Agribusiness, W. P. Carey School of Business, Arizona State University, Tempe, Arizona \\ HISHAM S. EL-OSTA \\ Economic Research Service, U.S. Department of Agriculture, Washington, DC
}

\begin{abstract}
This study investigates the factors likely to affect an individual's decision to enter farming after and/or while participating in an off-farm employment activity. Additionally, an ordered multivariate regression procedure was used to analyze the degree of importance of selected motivating reasons that were drivers of individuals' decision to enter farming. Results indicate that individuals with lower education, children in the household, and older family members were more likely to have entered farming as an occupation. Findings further suggest that federal policies in the form of farm program payments may provide retired nonfarm workers incentives to enter farming in later life.
\end{abstract}

Keywords. Beginning farmer, farm policy, income source, labor participation, occupational choice, ordered probit model

JEL Classifications. J26, Q12

\section{Introduction}

A long-standing practice has been that farmers in the older generation have arranged for successors to take over their farming operations. This has been particularly true in American agriculture where the majority of farm successions have been familial based (Mishra and El-Osta, 2008; Mishra, El-Osta, and Shaik, 2010). Laband and Lentz (1983) found that farmers were nearly five times more likely than other self-employed proprietors to have followed in their parents' footsteps in the business. The younger, often more educated farmers in the next generation have been more likely to work off the farm to increase and/or stabilize total household income (Mishra et al., 2002). Although members of the succeeding generation may desire to enter farming, some may forgo entering in the short run to pursue other economic opportunities off the farm. This delay

The authors acknowledge the helpful comments of three anonymous reviewers and the editor of Journal of Agricultural and Applied Economics. The views expressed are the authors' and do not necessarily represent the policies or views of the U.S. Department of Agriculture.

*E-mail: Ashok.K.Mishra@Asu.edu 
to entering farming may be further exacerbated by the fact that many U.S. farm operators work on their farms well beyond their retirement age. Thus, although the older generation continues farming, members of the next generation must decide whether to work alongside the older generation or pursue other economic opportunities prior to eventually taking over the farm, perhaps later in life.

Using the U.S. Department of Agriculture's (USDA) 2004 Agricultural Resource Management Survey (ARMS) data, we find that $60 \%$ of current farm operators reported working off the farm prior to taking on farming as their main occupation (USDA, Economic Research Service, 2011a). The average age of these farmers was approximately 55 with 14 years of education. There are several reasons why this might happen. For example, it could be due to a desire for change at midlife, ${ }^{1}$ parents of the reentrant may desire to retire from farming, or the entering individual may be unemployed and facing decreased off-farm employment prospects due to age. Another possibility is that the entrant may have hoped to return to the farm upon realizing financial security (retirement income, savings, and health benefits). Forgoing farming until financial security is realized would reduce the risk associated with pursuing a job with significant economic up- and downturns.

Another reason for entering farming as an occupation later in later life could be related to farm policy. Farm policy through commodity program payments has encouraged the propagation of larger farms and may have slowed the rate of exit from agriculture (Mishra, Fannin, and Joo, 2014). Barkley (1990) points out that the federal government's food policy (farm program payments) may have indirectly slowed the rate of migration from agriculture through higher land prices. Indeed, Mishra and El-Osta (2008) found that the likelihood of having a succession plan with a defined farm successor increases with expected government farm program payments, farm wealth, age, and educational level of the farm operator. Could farm program participation be a factor that brings individuals back to farming? In other words, might agricultural subsidies be a catalyst to occupational choice, particularly with regard to farming, in later life? ${ }^{2}$

A plethora of studies have investigated dual employment among farm families and farm exit. Only a limited number have investigated the reasons and factors affecting the predominance of intergenerational succession within the farm sector (Glauben, Tietje, and Weiss, 2004; Kimhi and Nachlieli, 2001; Mishra and ElOsta, 2008). None, however, have addressed whether the younger generation is working off the farm as full-time employment, or whether there is a likelihood

1 Ginzberg et al. (1966, p. 29) write, "The key to a study of occupational choice appears to lie in an appraisal of the way in which the individual, as he matures, reaches decisions with respect to his eventual occupation. This means that the analysis must follow the way in which he becomes increasingly aware of what he likes and what he dislikes; of what he does well and what he does poorly; the values which are meaningful to him and considerations which are unimportant."

2 Later life is defined here as retirement-after the age of 55 . Society uses this term to signify preretirement after the kids have grown up and have their own families. 
that these individuals will return to the farm. These phenomena lead us to ask, what are the factors that affect an individual's decision to undertake an occupation like farming later in life? Herein lay the objectives of this study. First, we investigate the factors affecting an individual's decision to become a farmer after having off-farm employment. Second, conditional on having worked off the farm before entering farming, we investigate the degree of importance of becoming a farmer as it relates to the following: (1) taking over the operation of the farm from a family member, (2) developing a farm business as an additional source of income, and (3) developing a farm business as a primary source of income. We use a unique data set collected in the 2004 national farm-level ARMS data. The analysis is conducted with the unique feature of a large representative sample comprising farms of different economic sizes located throughout the United States. Recently, policy makers and economists have been interested in assessing the impact of farm program payments on the growth and survival of farm businesses. This interest could be related to budgetary pressures and/or international trade negotiations. Regardless, interest in farm growth and survival is a hot topic among policy makers, as evidenced by the 2001 tax legislation $^{3}$ and the 2014 Farm Bill. Finally, the entry-exit process continues to be a factor in the agricultural sector's efforts to maintain global competitiveness and in allocating resources between agriculture and other sectors of the American economy.

\section{Literature Review}

In the 1960s, economists and sociologists (Burchinal, 1961; Ford and Box, 1967; Haller and Sewell, 1967; Portes, Haller, and Sewell, 1968) extensively analyzed farming as an occupation. Much of the focus was on what factors determined the choice of farming as an occupation for the sons and daughters of farm operators. Gasson (1969) surveyed eastern England farmers to assess their sons' levels of aspiration to become farmers and whether they had realistic economic outlooks for agriculture. Gasson (1968, p. 317) had earlier written, "Sons whose fathers have farms which are too small to provide a living should be made aware of their own prospects in farming, the range of opportunities open to them and the satisfactions that could be gained in other occupations before they commit to an unrewarding struggle in farming." Gasson's (1969) survey was conducted at a time when, in America, younger, more educated people were leaving farms and heading to cities and towns in search of a better future. Overall, the U.S. agricultural sector has experienced a decline in both the absolute level and relative importance of farm employment during the 20th century. Most rural areas of the United States have been reshaped by continued farm loss and an outmigration of residents (Mishra et al., 2002).

3 The Economic Growth and Tax Relief Reconciliation Act of 2001 was signed into law on June 7, 2001. Also, the Agriculture Act of 2014, better known as the 2014 Farm Bill, was signed into law on February 7, 2014. 
Although the literature investigating factors affecting individuals' entry into farming is relatively scarce, a significant literature has amassed investigating the factors affecting farm exit (Breustedt and Glauben, 2007; Kimhi and Bollman, 1999; Mishra, Fannin, and Joo, 2014; Pietola, Väre, and Lansink, 2003; Weiss, 1999). Understanding the dynamics of farm exit behavior provides insight into the entry decision, as factors leading to exit would likely be those that discourage entry. For example, Rahelizatovo and Gillespie (1999) showed that regional differences in milk production tended to simultaneously encourage exit and reduce entry or vice versa. Zepeda (1995) examined factors influencing net new entry, the difference between entry and exits, inherently recognizing that many of the same factors would influence both. Thus, we review much of the literature on farm exit, with implications for entry.

Previous research has shown mixed effects of government policy on farm exit. D'Antoni, Mishra, and Barkley (2012) concluded that agricultural subsidies were a factor in pushing labor off the farm. Specifically, increased direct government payments resulted in greater migration of labor from agriculture-subsidies acted as a pure income transfer. There is also evidence to suggest that long-standing conservation programs and commodity buyouts may be attributable to migration from agriculture (Edwards and DeHaven, 2001; USDA, 2011). On the other hand, a strand of literature focused on the effects of government payments on the labor allocation decisions of farm operators and spouses (Ahearn, El-Osta, and Dewbre, 2006; El-Osta, Mishra, and Ahearn, 2004; Goodwin and Mishra, 2004; Mishra, Fannin, and Joo, 2014; Serra, Goodwin, and Featherstone, 2005) has found that government payments, particularly decoupled payments (direct payments), decreased off-farm work by operators, essentially slowing migration out of agriculture. A study by Key and Roberts (2009) suggested that a reduction in coupled support payments would reduce the marginal value of on-farm work, thereby increasing off-farm labor hours, unlike the increase in the wealth effect due to coupled payments, which would have a decreasing effect. Furthermore, investigating structural change on Connecticut dairy farms, Foltz (2004) showed that U.S. dairy price policies such as the Milk Income Loss Contract, which establishes a price floor for dairy products, reduced the rate of dairy farm exit in Connecticut during 1997-2001.

Finally, Mishra and El-Osta (2008) argue that by reducing market risk, government farm programs create a disincentive for farmers to leave the industry. While studying farm succession patterns in U.S. agriculture, they found that farm program payments tended to increase the likelihood of having a succession plan and, in turn, increase the likelihood that the successor was a family member-a case where the farm was in existence. If this is the case, then two issues arise. First, is there a possibility that a person working off the farm at one stage would want to return and choose farming as his/her occupation? Second, if one chooses to become a farmer, what is the goal of the farmer? Is it to take over operation of the farm from a family member, develop a farm business as an 
additional source of income, or develop a farm business as a primary source of income?

\section{Conceptual Framework}

Previous research on occupational choice has focused on the neoclassical human capital theory (Becker, 1964). Boskin's (1974) study of U.S. men and women confirms three goals in occupational choice: workers choose occupations that (1) maximize the discounted present value of potential lifetime earnings, (2) entail the lowest training costs, and (3) offer the lowest discounted present value of expected earnings forgone due to unemployment. In the simplest form, human capital theory of occupational choice embodies two postulates. First, the variety of occupational choices is limited by the amount of training required. Training is purchased as an investment in human capital. Second, it is hypothesized that individuals select occupations in a manner that maximizes the present value of their lifetime earnings. Implicitly, selection is equivalent to maximizing the rate of return on one's human capital investment. The concepts of present value and internal rate of return are best suited for analyzing the effects of expected income on occupational choice. Lucas (1977) pointed out that human capital theory is preoccupied with wage and personal characteristics and tends to overlook nonpecuniary characteristics of jobs. Lucas (1977) stipulates that utility gained from one's job is a function of wage, nonwage job features, and personal characteristics. A study by Schmidt and Strauss (1975) develops a theoretical model of occupational choice.

For the purposes of this study, two occupational categories are relevant, offfarm employment and farming. We first use a probit model to estimate the likelihood that an individual $i$ chose farming as an occupation after working off the farm. In other words, we calculate the probability that the current farm operator worked off the farm before taking on farming as his or her main occupation. We then estimate, while benefiting from the theoretical underpinning of occupational decision making of individuals as highlighted by Schmidt and Strauss (1975), an ordered probit model to examine reasons for entering farming, conditional on the farmer having held an off-farm job prior to entering.

\section{Data}

Our data are from the ARMS, which is an annual survey conducted by the USDA Economic Research Service and the National Agricultural Statistics Service. The ARMS collects data to measure the financial conditions (farm income, expenses, assets, and debts) and operating characteristics of farm businesses, the cost of producing agricultural commodities, and the well-being of farm operator households. Each observation in the ARMS represents a number of similar farms, the particular number being the survey expansion factor (or the inverse of the probability of the surveyed farm being selected for surveying), which is referred 
to henceforth as the survey weight, or $w_{i}(i=1, \ldots, n$, where $n$ denotes sample size).

A farm is defined by the USDA as an establishment that sold or normally would have sold at least $\$ 1,000$ of agricultural products during the year (see http:/www.ers.usda.gov/topics/farm-economy/farm-household-well-being/ glossary.aspx). We maintain the null hypothesis of homoscedastic errors. Farms are organized as sole proprietorships, partnerships, family corporations, nonfamily corporations, or cooperatives. Data are collected from the senior operator (i.e., the person who makes most of the management decisions) on each farm. We excluded approximately 40,000 farms-namely, those organized as nonfamily corporations or cooperatives and those run by hired managers. ${ }^{4}$

The ARMS provides data necessary for estimating operator household income. The Current Population Survey (CPS), conducted by the U.S. Census Bureau, is the source of official U.S. household income statistics (U.S. Department of Commerce, U.S. Census Bureau, 2011). Thus, calculating an estimate of farm household income from ARMS that is consistent with CPS methodology allows comparison between farm operator household ${ }^{5}$ income and all U.S. households. The CPS definition of self-employment income is net revenue from the operation of a business by a person's own account. CPS self-employment income includes income received as cash but excludes in-kind or nonmoney receipts; its definition departs from a strictly cash concept by deducting depreciation, a noncash business expense, from income. Total income for the farm operator household includes that from the farm business, other farming activities, and earned and unearned off-farm sources.

The unique feature of the 2004 ARMS is that it queried the farm operator on occupational choice. Specifically, the survey asked: "Did you (the operator) work at your current or any other off-farm job prior to becoming a farm operator?" The survey then asked the farm operator to rate the importance ${ }^{6}$ of, among others, each of the following reasons for becoming a farm operator: (a) "take

4 The expanded number of farms deleted from each of the initial farm organization categories ( $\%$ of total population of farms) is as follows: sole proprietorships $=6,128(0.29 \%)$; partnerships $=$ $1,846(0.09 \%)$; family corporations $=5,239(0.25 \%)$; nonfamily corporations $=5,666(0.27 \%)$; and cooperatives $=21,124(1 \%)$. The remaining number of farms after these deletions was 2,067,373. Of this total, approximately $18 \%$ had earned less than $\$ 20,000$ in total farm household income. Farm operator households in this category in 2004 had average farm sales of approximately $\$ 91,000$. The average farm household in this category lost money from farming $(-\$ 22,000)$, and the main income source was from off-farm work $(\$ 17,000)$. Farmers in this group were much older than their counterparts with income of $\$ 20,000$ or more, with average age of 59 and 56 , respectively.

5 Visit http://www.ers.usda.gov/Briefing/WellBeing/ for definition of farm operator household. This website will also provide links to operator household income and balance sheet. For operator household income over time, see http://www.ers.usda.gov/Briefing/WellBeing/Gallery/historic.htm.

6 Although the ARMS questionnaire asked the operator to report any one of five levels of importance (e.g., 1 = very important, $2=$ somewhat important, $3=$ neutral, $4=$ somewhat unimportant, $5=$ not at all important) when describing the reason for becoming a farmer, thinness of sample points in some of the reported outcomes required the use of only three importance levels with the "neutral" level being at 
Table 1. Summary Statistics for the "Sample-Selection" Equation Depicting Off-Farm Work Participation Decision by the Farm Operator, 2004

\begin{tabular}{|c|c|c|c|}
\hline \multirow[b]{2}{*}{ Item } & \multicolumn{2}{|c|}{$\begin{array}{l}\text { Worked Off-Farm } \\
\text { during or before } \\
\text { Becoming a Farmer }\end{array}$} & \multirow[b]{2}{*}{ All Households } \\
\hline & No & Yes & \\
\hline Sample size & 3,476 & 3,230 & 6,706 \\
\hline Expanded number of farms & 823,388 & $1,243,985$ & $2,067,373$ \\
\hline Distribution of households (\%) & 39.8 & 60.2 & 100.00 \\
\hline \multicolumn{4}{|l|}{ Operator characteristics ${ }^{\mathrm{a}}$} \\
\hline Age & $59^{*}$ & 55 & 57 \\
\hline Education (years) & $13.02^{*}$ & 13.47 & 13.29 \\
\hline Gender: male $(=1)$ & 0.91 & 0.91 & 0.91 \\
\hline \multicolumn{4}{|l|}{ County characteristics ${ }^{\mathrm{b}}$} \\
\hline Farming-dependent county & $0.13^{*}$ & 0.09 & 0.11 \\
\hline Services-dependent county & 0.32 & 0.34 & 0.33 \\
\hline Population loss county & $0.16^{*}$ & 0.12 & 0.14 \\
\hline \% Employed in transportation and utilities in 2003 & 2.50 & 2.43 & 2.46 \\
\hline \% Employed in finance/insurance in 2003 & $5.41^{*}$ & 5.66 & 5.56 \\
\hline \% Employed in government in 2003 & 15.65 & 15.59 & 15.62 \\
\hline \% Employed in construction in 2003 & $5.75^{*}$ & 6.09 & 5.95 \\
\hline \% Employed in manufacturing in 2003 & 11.05 & 10.91 & 10.97 \\
\hline
\end{tabular}

a Source: 2004 Agricultural Resource Management Survey (version 1, phase III). Standard errors of all continuous variables are estimated using bootstrapping with 1,000 resamples. Differences in the means by off-farm work status of continuous variables are examined, with asterisk $(*)$ indicating that the respective means within each row are statistically different (at $5 \%$ level confidence interval).

${ }^{b}$ Source: Computed by Economic Research Service economists based on information from the U.S. Census Bureau and U.S. Bureau of Labor Statistics (for more detail, see USDA, Economic Research Service, 2011b).

over operations of the farm from a family member," (b) "develop a farm business as an additional source of income," and (c) "develop a farm business as a primary source of income.” This study also utilizes some auxiliary data. Specifically, local area characteristics in commuting zones are based on county-level data from the Bureau of Economic Analysis income files for 2003, the Bureau of Economic Analysis employment files for 2003, the Bureau of Labor Statistics, and the 2000 Census of Population, STF-3 file (U.S. Department of Commerce, Bureau of the Census, 2003; U.S. Department of Commerce, Bureau of Economic Analysis, 2003; U.S. Department of Labor, Bureau of Labor Statistics, 2003) (for more detail, see USDA, Economic Research Service, 2011b). Summary statistics and description of the variables used in the analysis are presented in Table 1.

the center. Furthermore, the survey has also asked for other reasons that might have prompted the farmer to enter into farming, which will be the subject of future research (e.g., to invest in real estate, to live in a rural area, as retirement activity/residence, etc.). 
Table 1 presents summary statistics for households having off-farm work while farming or prior to becoming a farmer. The survey covers 6,706 households, which expands to 2 million households when allowing for expansion factors for similar farm households. This allows us to examine previous farm entry decisions of the population of U.S. farmers. Sixty percent of the households had worked off the farm before entering the farming sector. Means comparisons suggest that the operators of farm households with no previous off-farm job were relatively older and had lower educational attainment, perhaps because of their on-farm employment alternatives and the potential for improved production performance from farming experience (see Ahearn, Perry, and ElOsta, 1993; Goodwin, Featherstone, and Zeuli, 2002). The sample covers farming-dependent counties (11\%), manufacturing-dependent counties $(33 \%)$, financial service and government-dependent counties $(10 \%)$, population loss counties $(14 \%)$, and other county types (see Figure 1 for delineation of farm location by county type). In 2003, households where the farm operator had previously held an off-farm job were present in significantly lower proportions in farming-dependent and population loss counties, as well as in counties with lower percentages of employment in the finance/insurance and construction sectors.

\section{Empirical Estimation}

The ordered response model used in this study follows the ordered probit model with self-selection as delineated by De Luca and Perotti (2011):

$$
\begin{gathered}
Y_{j}^{*}=\beta_{j}^{\prime} X_{j}+\varepsilon_{j}, \quad j=1,2 \\
Y_{1}=I\left(U_{j}^{*} \geq 0\right)=I(A) \\
Y_{2}=\sum_{h=0}^{H} h I\left(\alpha_{h}<Y_{j}^{*} \leq \alpha_{h+1}\right) \quad \text { if } Y_{1}=1,
\end{gathered}
$$

where $Y_{1}^{*}$ and $Y_{2}^{*}$ are continuous latent variables for the process representing sample selection and the ordered outcomes. $\beta_{j}$ in equation (1) is a vector of $k_{j}$ parameters to be estimated, $X$ is a vector of exogenous covariates, and $\varepsilon_{j}$ represents random errors with $\varepsilon_{1}$ and $\varepsilon_{2}$ following a bivariate normal distribution with zero means, unit variance, and correlation coefficient $\rho$. $I(A)$ in the observational rule (equation 2) is an indicator function of event $A$ that links the latent variable $Y_{1}^{*}$ to the binary variable $Y_{1}$. The observational rule (equation 3) links the latent variable $Y_{2}^{*}$ to outcome $Y_{2}$ with $\alpha=\left(\alpha_{1}, \cdots, \alpha_{H} ; \alpha_{0}=-\infty\right.$, and $\left.\alpha_{H+1}=+\infty\right)$ denoting a vector of monotonically increasing thresholds, which divide $Y_{2}^{*}$, while using $h$ to represent the ordered outcomes of event $A$, into $H+1$ exhaustive and mutually 

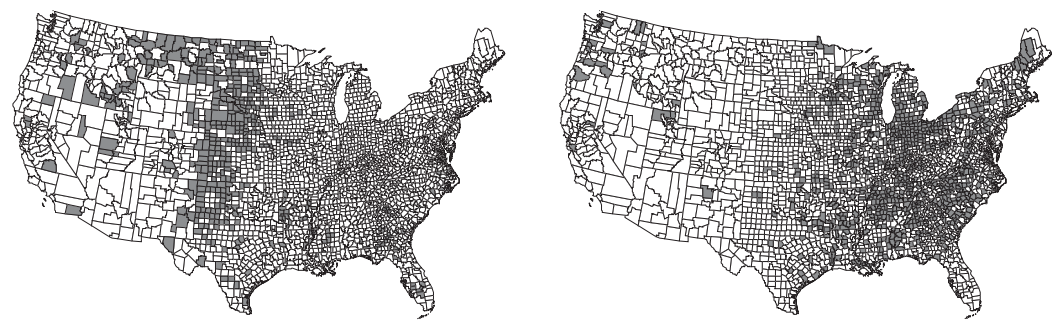

$\begin{array}{lll}\text { (c) Federal/State government-dependent counties, 1998-2000 } & \text { (d) Services-dependent counties, 1998-2000 }\end{array}$
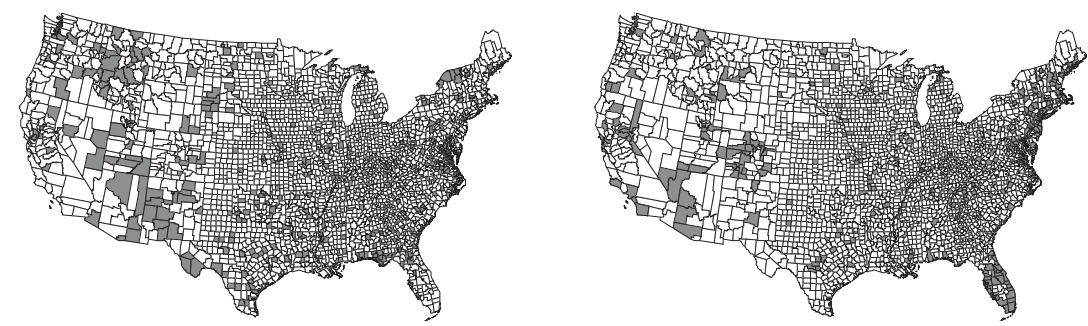

(e) Population loss counties, 1980-1990 and 1990-2000

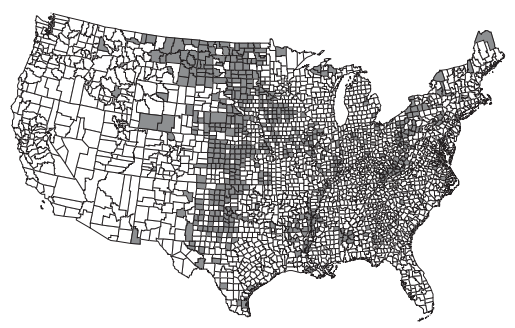

Figure 1. Delineation of Farm Location by County Type

exclusive segments (see Greene, 2008, p. 833). In this study, the binary variable $Y_{1}$ represents the off-farm labor participation decision of the operator during and/or prior to entering farming (or event $A$ ), and $Y_{2}$ represents the ordered rating (or outcome) of the importance of the reason for farm entry itself conditional on the occurrence of a prior off-farm labor participation decision.

Estimation of the sample-selection ordered probit model (De Luca and Perotti, $2011)$ is based on the maximization of the $\log$-likelihood function $\log L(\tilde{\theta})$, which has an underlying random sample of $n$ observations $\left\{\left(Y_{1 i}, Y_{2 i}, X_{1 i}, X_{2 i}\right) ; i=1\right.$, 
$\ldots, n\}$ over the parameter space $\Phi=\Re^{k_{1}+k_{2}+H x(-1,1)}$ :

$\underset{\tilde{\theta} \in \Phi}{\operatorname{Max}} \log L(\tilde{\theta})=\sum_{i=1}^{\mathrm{n}}\left[\left(1-Y_{1 i}\right) \log \pi_{0 i}(\theta)+\sum_{h=0}^{H} Y_{1 i} I\left(Y_{2 i}=h\right) \log \pi_{1 h i}(\theta)\right]$

where $\theta=\left(\beta_{1}, \beta_{2}, \alpha, \rho\right)$ is a vector of parameters of the "event" and the "outcome" models, and $\left(\pi_{0}, \pi_{10}, \cdots, \pi_{1 H}\right)$ represents the conditional probabilities reflecting the $H+2$ possible realizations of $Y_{1}$ and $Y_{2}$, which are estimated as follows:

$$
\begin{aligned}
\pi_{0}(\tilde{\theta}) & =\operatorname{Pr}\left\{Y_{1}=0\right\}=1-\Phi\left(\beta_{1}^{\prime} X_{1}\right) \\
\pi_{1 h}(\tilde{\theta}) & =\operatorname{Pr}\left\{Y_{1}=1, Y_{2}=h\right\} \\
& =\Phi_{2}\left(\beta_{1}^{\prime} X_{1}, \alpha_{h+1}-\beta_{2}^{\prime} X_{2} ;-\rho\right)-\Phi_{2}\left(\beta_{1}^{\prime} X_{1}, \alpha_{h}-\beta_{2}^{\prime} X_{2} ;-\rho\right),
\end{aligned}
$$

with $\Phi$ denoting the standardized normal distribution, $\Phi_{2}$ denoting the bivariate normal distribution with means and variances of 0 and 1 , respectively, and correlation coefficient $\rho$.

The marginal effects of the explanatory variables of the sample-selection ordered probit model across the $h_{1,2,3}$ ordered outcomes as considered in this study are computed as in the following (see Duncan, Khattak, and Council, 1998):

$$
\begin{aligned}
\partial \pi_{1 h}\left(Y_{1}=1, Y_{2}=h\right) / \partial X_{2}= & -\left[\Phi_{2}\left(\beta_{1}^{\prime} X_{1}, \alpha_{h+1}-\beta_{2}^{\prime} X_{2} ;-\rho\right)\right. \\
& \left.-\Phi_{2}\left(\beta_{1}^{\prime} X_{1}, \alpha_{h}-\beta_{2}^{\prime} X_{2} ;-\rho\right)\right] \beta_{2} .
\end{aligned}
$$

\section{Results and Discussion}

Table 2 presents summary statistics of the relative importance of reasons for becoming a farm operator ${ }^{7}$ across operator and household characteristics. Significant differences across the three reasons were found for farm sales and the entropy index, which is a measure of farm diversification. ${ }^{8}$ Farm operators

7 These include (1) take over operation of the farm from a family member, (2) develop a farm business as an additional source of income, and (3) develop a farm business as a primary source of income.

8 The extent of farm diversification among $N$ possible enterprises is measured using the following index (see Theil, 1971) and by letting $x_{j}=(\%$ value of production from enterprise $j)$ :

Entropy $_{i}=\sum_{j=1}^{N}\left(x_{j}\right) \frac{\log \left[\frac{1}{\left(x_{j}\right)}\right]}{\log (N)}$,

where the index ranges from $0 \%$ (i.e., a completely specialized farm producing only one commodity) to $100 \%$ (i.e., a completely diversified farm with equal shares of each commodity). 
Table 2. Summary Statistics for the "Ordered Probit Sample-Selection” Model of the Importance of Reasons for Becoming a Farm Operator, 2004

\begin{tabular}{|c|c|c|c|c|}
\hline \multirow[b]{2}{*}{ Item } & \multicolumn{3}{|c|}{$\begin{array}{l}\text { Reported Level of Importance }{ }^{\mathrm{a}} \text { Very or Somewhat Important } \\
\qquad(\text { Outcome }=3)\end{array}$} & \multirow[b]{2}{*}{$\begin{array}{l}\text { All } \\
\text { Households }\end{array}$} \\
\hline & $\begin{array}{l}\text { Take Over Operation } \\
\text { of the Farm from a } \\
\text { Family Member }\end{array}$ & $\begin{array}{l}\text { Develop a Farm } \\
\text { Business as an } \\
\text { Additional } \\
\text { Source of } \\
\text { Income }\end{array}$ & $\begin{array}{l}\text { Develop a Farm } \\
\text { Business as a Primary } \\
\text { Source of Income }\end{array}$ & \\
\hline \multicolumn{5}{|l|}{ Operator characteristics } \\
\hline Age: $35-44(=1)$ & 0.14 & 0.14 & 0.14 & 0.14 \\
\hline Age: $45-54(=1)$ & 0.24 & 0.30 & 0.25 & 0.26 \\
\hline Age: $45-64(=1)$ & 0.39 & 0.34 & 0.38 & 0.30 \\
\hline Age: 65 or older $(=1)$ & 0.18 & 0.18 & 0.19 & 0.27 \\
\hline Education: completed high school $(=1)$ & 0.45 & 0.44 & 0.48 & 0.42 \\
\hline Education: some college $(=1)$ & 0.24 & 0.22 & 0.22 & 0.24 \\
\hline Education: college $(=1)$ & 0.17 & 0.17 & 0.16 & 0.16 \\
\hline Education: graduate school $(=1)$ & 0.07 & 0.08 & 0.04 & 0.07 \\
\hline Gender: male $(=1)$ & 0.91 & 0.92 & 0.95 & 0.91 \\
\hline Race: white $(=1)$ & 0.84 & 0.87 & 0.82 & 0.93 \\
\hline Marital status: married $(=1)$ & 0.83 & 0.88 & 0.86 & 0.84 \\
\hline Presence of children under $17(=1)$ & 0.37 & 0.40 & 0.40 & 0.30 \\
\hline Presence of individuals 65 or older $(=1)$ & 0.32 & 0.29 & 0.34 & 0.33 \\
\hline \multicolumn{5}{|l|}{ Household and farm characteristics } \\
\hline Household receiving direct payments $(=1)$ & 0.23 & 0.17 & 0.27 & 0.22 \\
\hline Household receiving countercyclical payments $(=1)$ & 0.13 & 0.10 & 0.16 & 0.14 \\
\hline Household receiving LDPs $(=1)$ & 0.16 & 0.11 & 0.20 & 0.14 \\
\hline Household receiving CRP payments $(=1)$ & 0.16 & 0.11 & 0.14 & 0.14 \\
\hline Household receiving all other payments $(=1)$ & 0.10 & 0.08 & 0.13 & 0.10 \\
\hline Farm sales $(\$ 1,000)$ in 2003 & $57.74^{*}$ & $38.59^{*}$ & $86.00^{*}$ & $66.72^{*}$ \\
\hline Farm acreage fully owned $(=1)$ & 0.60 & 0.62 & 0.52 & 0.60 \\
\hline
\end{tabular}


Table 2. Continued

\begin{tabular}{|c|c|c|c|c|}
\hline \multirow[b]{2}{*}{ Item } & \multicolumn{3}{|c|}{$\begin{array}{l}\text { Reported Level of Importance }{ }^{\mathrm{a}} \text { : Very or Somewhat Important } \\
\qquad \text { (Outcome }=3)\end{array}$} & \multirow[b]{2}{*}{$\begin{array}{l}\text { All } \\
\text { Households }\end{array}$} \\
\hline & $\begin{array}{l}\text { Take Over Operation } \\
\text { of the Farm from a } \\
\text { Family Member }\end{array}$ & $\begin{array}{l}\text { Develop a Farm } \\
\text { Business as an } \\
\text { Additional } \\
\text { Source of } \\
\text { Income }\end{array}$ & $\begin{array}{l}\text { Develop a Farm } \\
\text { Business as a Primary } \\
\text { Source of Income }\end{array}$ & \\
\hline Farm acreage partly owned $(=1)$ & 0.32 & 0.32 & 0.39 & 0.34 \\
\hline Entropy index & $0.14^{*}$ & $0.12^{*}$ & $0.14^{*}$ & $0.14^{*}$ \\
\hline Farm organization: sole proprietorship $(=1)$ & 0.91 & 0.93 & 0.91 & 0.92 \\
\hline Farm location: Midwest region $(=1)^{\mathrm{b}}$ & 0.3 & 0.33 & 0.41 & 0.38 \\
\hline
\end{tabular}

a Summary statistics for reported levels of importance of "somewhat unimportant or not at all important" (outcome $=1$ ) and "neutral" (outcome $=2$ ) are left out to save space. The asterisk $\left(^{*}\right)$ indicates means for continuous variables are statistically significant at $5 \%$ (standard deviations are computed using 1,000 bootstrap replicate samples).

b The Midwest region is based on delineation by the U.S. Census Bureau. Specifically, it includes the East North Central division (Indiana, Illinois, Michigan, Ohio, and Wisconsin) and the West North Central division (Iowa, Nebraska, Kansas, North Dakota, Minnesota, South Dakota, and Missouri).

Note: CRP, conservation reserve program; LDP, loan deficiency payment.

Source: 2004 Agricultural Resource Management Survey (version 1, phase III). 
reporting "develop a farm business as a primary source of income" as a somewhat or very important reason for entering farming had significantly higher farm sales $(\$ 86,000)$ compared with those reporting the same response for "develop a farm business as an additional source of income" $(\$ 38,590)$. Farm operators reporting "take over operation of the farm from a family member" as a somewhat or very important reason for entering farming had mean farm sales of $\$ 57,700$. These results suggest that households choosing to farm with the aim of developing the farm business as a primary source of income were more likely to have realized a farm income level that would meet that goal. Finally, farm operators having chosen to enter farming for a primary income source or for taking over the family business had significantly $(P \leq 0.05)$ higher entropy indices (were more diversified) than those entering for an additional income source. Response means did not differ significantly across the three reasons for entering farming by operator characteristics such as age groups, educational attainment, gender, race, marital status, the presence of children, or the presence of elderly individuals within the household. Furthermore, response means did not differ significantly across the three reasons for whether the household received government payments or for farm ownership, organization, or location.

Table 3 presents the parameter estimates of the ordered probit sampleselection model. We report (1) the coefficients and $z$-statistics for factors affecting the previous off-farm work decision and (2) the ordered probit regression results conditional on previous off-farm work experience for the selected sample. Marginal effects of the ordered probit are calculated at each of the integer values of the dependent variable ranging from 1 to 3 (less or unimportant, neutral, and very or somewhat important, respectively) evaluated at the means of the continuous variables. For the ordered probit, the less and unimportant reasons were combined, as well as the very and somewhat important reasons, due to thinness in numbers of observations in some of the categories. Marginal effects of indicator or dummy variables were computed as the difference in choosing probabilities under each reason when the dummy variable was 0 and 1 , all other variables held at their mean values. Marginal effects for each of the three reasons are presented in Table 4. Note that as the nature of the ordered probit suggests, signs of the marginal effects for the highest outcome (very or somewhat important, outcome 3 ) are the same as those for the Table 3 coefficients, whereas signs for the lowest outcomes (somewhat unimportant or not at all important, outcome 1) have the opposite signs.

\subsection{Off-Farm Work Decision Model}

Results indicate that current and/or previous off-farm work decisions are influenced by farm operator attributes and location-specific variables. For all three models, operator age and educational attainment were significant factors in the decision whether to work off the farm prior to entering farming. More highly educated farmers were more likely to have entered farming after off-farm 
Table 3. Estimation Results of the "Ordered Probit Sample-Selection” Model of the Importance of Reasons for Becoming a Farm Operator, 2004

\begin{tabular}{|c|c|c|c|c|c|c|}
\hline & \multicolumn{2}{|c|}{$\begin{array}{l}\text { Take Over Operation } \\
\text { of the Farm from } \\
\text { a Family Member }\end{array}$} & \multicolumn{2}{|c|}{$\begin{array}{c}\text { Develop a Farm Business } \\
\text { as an an Additional } \\
\text { Source of Income }\end{array}$} & \multicolumn{2}{|c|}{$\begin{array}{c}\text { Develop a Farm Business } \\
\text { as a a Primary } \\
\text { Source of Income }\end{array}$} \\
\hline & Coefficient & $z$-Statistic & Coefficient & $z$-Statistic & Coefficient & $z$-Statistic \\
\hline \multicolumn{7}{|l|}{ Ordered probit } \\
\hline Age: $35-44$ & 0.0495 & 0.37 & -0.2887 & -1.18 & $-0.2350^{*}$ & -1.66 \\
\hline Age: $45-54$ & 0.1056 & 0.79 & 0.0207 & 0.12 & -0.0765 & -0.54 \\
\hline Age: $45-64$ & 0.2180 & 1.54 & -0.1559 & -0.84 & -0.0401 & -0.27 \\
\hline Age: 65 or older & $-0.4490^{* *}$ & -2.52 & $-0.7652^{* * *}$ & -3.10 & $-0.6990^{* * *}$ & -3.81 \\
\hline Education: completed high school & $0.2018^{* *}$ & 2.19 & $0.2355^{* * *}$ & 2.05 & 0.1051 & 1.00 \\
\hline Education: some college & $0.2042^{* *}$ & 1.97 & 0.1542 & 1.03 & 0.1050 & 0.93 \\
\hline Education: college & 0.1824 & 1.57 & 0.1616 & 0.84 & 0.0561 & 0.46 \\
\hline Education: graduate school & 0.0472 & 0.32 & $0.3258^{*}$ & 1.71 & $-0.3023^{*}$ & -1.91 \\
\hline Gender: male & -0.1088 & -0.87 & -0.0246 & -0.17 & 0.0711 & 0.64 \\
\hline Race: white & $-0.4476^{* * *}$ & -3.33 & $-0.4520^{*}$ & -1.81 & $-0.6554^{* * *}$ & -4.70 \\
\hline Marital status: married & $-0.2514^{* * *}$ & -3.19 & 0.1826 & 1.54 & -0.0429 & -0.51 \\
\hline Presence of children under 17 & 0.1150 & 1.63 & $0.2675^{* *}$ & 2.15 & $0.2104^{* * *}$ & 2.80 \\
\hline Presence of individuals 65 or older & $0.3332^{* * *}$ & 3.18 & $0.3230^{*}$ & 1.88 & $0.4205^{* * *}$ & 3.72 \\
\hline Household receiving direct payments & 0.0879 & 0.94 & 0.0828 & 0.81 & 0.1100 & 0.95 \\
\hline Household receiving countercyclical payments & -0.0348 & -0.38 & 0.0754 & 0.61 & -0.0147 & -0.13 \\
\hline Household receiving LDPs & $0.3573^{* * *}$ & 3.21 & -0.0109 & -0.09 & $0.3815^{* * *}$ & 2.73 \\
\hline Household receiving CRP payments & $0.1940^{*}$ & 1.71 & -0.0298 & -0.29 & 0.0309 & 0.33 \\
\hline Household receiving all other payments & 0.0110 & 0.11 & 0.0259 & 0.23 & $0.2178^{*}$ & 1.79 \\
\hline Farm sales $(\$ 1,000)$ in 2003 & 0.0001 & 0.69 & $-0.0006^{* *}$ & -2.03 & $0.0027^{* * *}$ & 4.13 \\
\hline Farm acreage fully owned & $-0.2576^{*}$ & -1.89 & -0.0812 & -0.58 & -0.2467 & -1.77 \\
\hline Farm acreage partly owned & -0.1761 & -1.30 & 0.1638 & 1.17 & 0.0087 & 0.06 \\
\hline Entropy index & $0.6302^{* *}$ & 2.37 & -0.2993 & -0.83 & 0.3772 & 1.32 \\
\hline Farm organization: sole proprietorship & $-0.2762^{* *}$ & -2.45 & -0.2203 & -1.55 & $-0.1875^{* *}$ & -1.66 \\
\hline Farm location: Midwest region & -0.0305 & -0.46 & -0.0665 & -0.83 & 0.0633 & 0.89 \\
\hline
\end{tabular}


Table 3. Continued

\begin{tabular}{|c|c|c|c|c|c|c|}
\hline & \multicolumn{2}{|c|}{$\begin{array}{l}\text { Take Over Operation } \\
\text { of the Farm from } \\
\text { a Family Member }\end{array}$} & \multicolumn{2}{|c|}{$\begin{array}{l}\text { Develop a Farm Business } \\
\text { as an an Additional } \\
\text { Source of Income }\end{array}$} & \multicolumn{2}{|c|}{$\begin{array}{c}\text { Develop a Farm Business } \\
\text { as a a Primary } \\
\text { Source of Income }\end{array}$} \\
\hline & Coefficient & $z$-Statistic & Coefficient & $z$-Statistic & Coefficient & $z$-Statistic \\
\hline \multicolumn{7}{|l|}{ Off-farm work decision "selection model" } \\
\hline Age & $0.0406^{* * *}$ & 3.22 & $0.0381^{* * *}$ & 2.72 & $0.0421^{* * *}$ & 3.07 \\
\hline Age, squared & $-0.0005^{* * *}$ & -4.26 & $-0.0004^{* * *}$ & -3.56 & $-0.0005^{* * *}$ & -3.97 \\
\hline Education & $0.0480^{* * *}$ & 3.63 & $0.0466^{* * *}$ & 3.47 & $0.0456^{* * *}$ & 3.46 \\
\hline Gender: male & 0.0695 & 0.65 & 0.0494 & 0.45 & 0.0588 & 0.54 \\
\hline Farming-dependent county & $-0.2392^{* * *}$ & -2.70 & -0.2063 & -1.46 & $-0.2627^{* * *}$ & -2.77 \\
\hline Services-dependent county & -0.0522 & -0.56 & -0.1342 & -1.20 & -0.1259 & -1.25 \\
\hline Population loss county & -0.0687 & -0.94 & -0.0946 & -0.97 & -0.0919 & -1.16 \\
\hline$\%$ Employed in transportation and utilities in 2003 & -0.0001 & -0.01 & -0.0069 & -0.38 & -0.0078 & -0.68 \\
\hline$\%$ Employed in finance/insurance in 2003 & 0.0151 & 1.22 & 0.0087 & 0.65 & 0.0182 & 1.31 \\
\hline \% Employed in government in 2003 & -0.0003 & -0.06 & -0.0044 & -0.81 & -0.0018 & -0.31 \\
\hline \% Employed in construction in 2003 & 0.0134 & 1.31 & 0.0177 & 1.49 & 0.0169 & 1.54 \\
\hline \% Employed in manufacturing in 2003 & -0.0016 & -0.41 & -0.0054 & -1.35 & -0.0030 & -0.71 \\
\hline Constant & $-1.2754^{* * *}$ & -2.80 & $-1.0182^{* * *}$ & -2.18 & $-1.2484^{* * *}$ & -2.58 \\
\hline Thresholds & & & & & & \\
\hline /cut1 & -0.4796 & -1.20 & -0.6855 & -0.61 & -0.5080 & -1.42 \\
\hline /cut2 & -0.1833 & -0.46 & -0.2355 & -0.25 & 0.0358 & 0.11 \\
\hline Rho & \multirow{2}{*}{\multicolumn{2}{|c|}{$\begin{array}{c}0.8561 \\
6.13\left(\begin{array}{c}\text { Probability }>\chi^{2}= \\
0.01)\end{array}\right.\end{array}$}} & \multirow{2}{*}{\multicolumn{2}{|c|}{$\begin{array}{c}0.6467 \\
0.37\left(\text { Probability }>\chi^{2}=\right. \\
0.54)\end{array}$}} & \multirow{2}{*}{\multicolumn{2}{|c|}{$\begin{array}{c}0.7037 \\
8.57 \text { Probability }>\chi^{2}= \\
0.0034)\end{array}$}} \\
\hline Wald test of independence of equations $($ rho $=0$ ) & & & & & & \\
\hline
\end{tabular}

Notes: Statistical significance is based on heteroscedasticity robust standard errors: ${ }^{*}, P<0.10{ }^{* *}, P<0.05 ;{ }^{* * *}, P<0.01$. CRP, conservation reserve program; LDP, loan deficiency payment. 
Table 4. Marginal Effects of the "Ordered Probit Sample-Selection” Models, 2004

\begin{tabular}{|c|c|c|c|}
\hline & $\begin{array}{l}\text { Take Over } \\
\text { Operation of } \\
\text { the Farm from } \\
\text { a Family } \\
\text { Member }\end{array}$ & $\begin{array}{l}\text { Develop a } \\
\text { Farm Business } \\
\text { as an } \\
\text { Additional } \\
\text { Source of } \\
\text { Income }\end{array}$ & $\begin{array}{l}\text { Develop a } \\
\text { Farm Business } \\
\text { as a Primary } \\
\text { Source of } \\
\text { Income }\end{array}$ \\
\hline \multicolumn{4}{|c|}{ Outcome (1): "somewhat unimportant or not at all important" } \\
\hline Age: $35-44$ & -0.0260 & 0.1144 & 0.1052 \\
\hline Age: $45-54$ & -0.0552 & -0.0076 & 0.0333 \\
\hline Age: $45-64$ & -0.1129 & 0.0589 & 0.0174 \\
\hline Age: 65 or older & $0.2368^{* * *}$ & $0.3084^{* *}$ & $0.3132 * * *$ \\
\hline Education: completed high school & $-0.1055^{* *}$ & -0.0854 & -0.0451 \\
\hline Education: some college & $-0.1054^{*}$ & -0.0550 & -0.0446 \\
\hline Education: college & -0.0939 & -0.0570 & -0.0240 \\
\hline Education: graduate school & -0.0247 & -0.1059 & $0.1374^{*}$ \\
\hline Gender: male & 0.0767 & 0.0165 & -0.0195 \\
\hline Race: white & $0.2123^{* * *}$ & $0.1393^{* * *}$ & $0.2264^{* * *}$ \\
\hline Marital status: married & $0.1278^{* * *}$ & $-0.0705^{* *}$ & 0.0183 \\
\hline Presence of children under 17 & -0.0601 & $-0.0943^{* * *}$ & $-0.0884^{* * *}$ \\
\hline Presence of individuals 65 or older & $-0.1707^{* * *}$ & $-0.1135^{* * *}$ & $-0.1722^{* * *}$ \\
\hline Household receiving direct payments & -0.0460 & -0.0300 & -0.0466 \\
\hline Household receiving countercyclical payments & 0.0184 & -0.0272 & 0.0064 \\
\hline Household receiving LDPs & $-0.1770^{* * *}$ & 0.0041 & $-0.1498^{* * *}$ \\
\hline Household receiving CRP payments & $-0.0995^{* *}$ & 0.0111 & -0.0132 \\
\hline Household receiving all other payments & -0.0058 & -0.0095 & $-0.0890^{* *}$ \\
\hline Farm sales $(\$ 1,000)$ in 2003 & -0.0001 & $0.0002^{* * *}$ & $-0.0012^{* * *}$ \\
\hline Farm acreage fully owned & $0.1340^{* *}$ & 0.0298 & $0.1046^{*}$ \\
\hline Farm acreage partly owned & 0.0932 & -0.0591 & -0.0037 \\
\hline Entropy index & $-0.3321^{* *}$ & 0.1104 & -0.1627 \\
\hline Farm organization: sole proprietorship & $0.1383^{* * *}$ & $0.0750^{* *}$ & $0.0770 *$ \\
\hline Farm location: Midwest region & 0.0161 & 0.0247 & -0.0272 \\
\hline \multicolumn{4}{|l|}{ Outcome (2): "neutral" } \\
\hline Age: $35-44$ & 0.0000 & 0.0177 & 0.0006 \\
\hline Age: $45-54$ & -0.0003 & -0.0018 & 0.0020 \\
\hline Age: $45-64$ & -0.0019 & 0.0123 & 0.0012 \\
\hline Age: 65 or older & -0.0144 & 0.0316 & -0.0140 \\
\hline Education: completed high school & 0.0000 & $-0.0212^{* *}$ & -0.0037 \\
\hline Education: some college & -0.0023 & -0.0146 & -0.0044 \\
\hline Education: college & -0.0025 & -0.0158 & -0.0022 \\
\hline Education: graduate school & -0.0000 & -0.0365 & -0.0039 \\
\hline Gender: male & -0.0000 & 0.0035 & -0.0025 \\
\hline Race: white & 0.0240 & $0.0535^{* *}$ & $0.0750^{* * *}$ \\
\hline Marital status: married & 0.0053 & -0.0132 & 0.0016 \\
\hline Presence of children under 17 & -0.0002 & $-0.0258^{* * *}$ & $-0.0099^{*}$ \\
\hline Presence of individuals 65 or older & -0.0043 & $-0.0312^{* *}$ & $-0.0237^{* *}$ \\
\hline Household receiving direct payments & -0.0002 & -0.0076 & -0.0048 \\
\hline Household receiving countercyclical payments & -0.0003 & -0.0071 & 0.0005 \\
\hline Household receiving LDPs & -0.0124 & 0.0010 & -0.0296 \\
\hline Household receiving CRP payments & -0.0032 & 0.0025 & -0.0011 \\
\hline
\end{tabular}


Table 4. Continued

\begin{tabular}{|c|c|c|c|}
\hline & $\begin{array}{l}\text { Take Over } \\
\text { Operation of } \\
\text { the Farm from } \\
\text { a Family } \\
\text { Member }\end{array}$ & $\begin{array}{l}\text { Develop a } \\
\text { Farm Business } \\
\text { as an } \\
\text { Additional } \\
\text { Source of } \\
\text { Income }\end{array}$ & $\begin{array}{l}\text { Develop a } \\
\text { Farm Business } \\
\text { as a Primary } \\
\text { Source of } \\
\text { Income }\end{array}$ \\
\hline Household receiving all other payments & 0.0000 & -0.0023 & -0.0136 \\
\hline Farm sales $(\$ 1,000)$ in 2003 & 0.0000 & $0.0001^{* *}$ & -0.0001 \\
\hline Farm acreage fully owned & 0.0008 & 0.0072 & 0.0101 \\
\hline Farm acreage partly owned & -0.0024 & -0.0150 & -0.0003 \\
\hline Entropy index & 0.0035 & 0.0259 & -0.0123 \\
\hline Farm organization: sole proprietorship & 0.0086 & $0.0230^{*}$ & 0.0112 \\
\hline Farm location: Midwest region & -0.0002 & 0.0056 & -0.0022 \\
\hline \multicolumn{4}{|l|}{ Outcome (3): "very or somewhat important" } \\
\hline Age: $35-44$ & 0.0260 & -0.1321 & $-0.1058^{*}$ \\
\hline Age: $45-54$ & 0.0554 & 0.0094 & -0.0353 \\
\hline Age: $45-64$ & 0.1147 & -0.0712 & -0.0186 \\
\hline Age: 65 or older & $-0.2223^{* * *}$ & $-0.3399 * * *$ & $-0.2991^{* * *}$ \\
\hline Education: completed high school & $0.1054^{* *}$ & 0.1066 & 0.0488 \\
\hline Education: some college & $0.1077^{* *}$ & 0.0696 & 0.0490 \\
\hline Education: college & 0.0964 & 0.0727 & 0.0262 \\
\hline Education: graduate school & 0.0248 & 0.1424 & $-0.1334^{* *}$ \\
\hline Gender: male & -0.0767 & -0.0200 & 0.0220 \\
\hline Race: white & $-0.2363^{* * *}$ & $-0.1928^{* * *}$ & $-0.3013^{* * *}$ \\
\hline Marital status: married & $-0.1332^{* * *}$ & $0.0836^{* *}$ & -0.0199 \\
\hline Presence of children under 17 & 0.0603 & $0.1201^{* * *}$ & $0.0983^{* * *}$ \\
\hline Presence of individuals 65 or older & $0.1750^{* * *}$ & $0.1447^{* * *}$ & $0.1960^{* * *}$ \\
\hline Household receiving direct payments & 0.0462 & 0.0375 & 0.0514 \\
\hline Household receiving countercyclical payments & -0.0181 & 0.0342 & -0.0068 \\
\hline Household receiving LDPs & $0.1894^{* * *}$ & -0.0050 & $0.1794^{* * *}$ \\
\hline Household receiving CRP payments & $0.1027^{* *}$ & -0.0136 & 0.0144 \\
\hline Household receiving all other payments & 0.0058 & 0.0118 & $0.1025^{*}$ \\
\hline Farm sales $(\$ 1,000)$ in 2003 & 0.0001 & $-0.0003^{* * *}$ & $0.0013^{* * *}$ \\
\hline Farm acreage fully owned & $-0.1348^{* *}$ & -0.0369 & $-0.1147^{*}$ \\
\hline Farm acreage partly owned & -0.0908 & 0.0741 & 0.0040 \\
\hline Entropy index & $0.3286^{* *}$ & -0.1363 & 0.1750 \\
\hline Farm organization: sole proprietorship & $-0.1468^{* * *}$ & $-0.0981^{* *}$ & $-0.0882^{*}$ \\
\hline Farm location: Midwest region & -0.0159 & -0.0303 & 0.0294 \\
\hline
\end{tabular}

Notes: Statistical significance is based on standard errors computed based on the Delta method: *, $P<$ 0.10 ; ${ }^{* *}, P<0.05$; $^{* *}, P<0.01$. CRP, conservation reserve program; LDP, loan deficiency payment.

work. This result is not surprising given the greater opportunity costs to farming associated with higher educational attainment. Findings here are consistent with Kimhi and Bollman (1999), Kimhi (2000), and Ahituv and Kimhi (2002).

Farm operators in farming-dependent counties were less likely to have worked off the farm and less likely to agree that they had chosen farming for reasons of family takeover or development of the farm business as a primary source of 
income. These results reflect the lower supply of off-farm relative to farm jobs in farming-dependent areas.

\subsection{Operator and Farm Characteristics of Households and Reasons for Choosing Farming as an Occupation}

Examining the parameter estimates and marginal effects presented in Tables 3 and 4 , respectively, one can interpret the results of factors driving decisions to become a farm operator in later life. Estimates in Table 3 show that operators 65 or older, married, white, having full ownership of the farm, and being a sole proprietor were less likely to have entered farming conditional on having worked off the farm for the reason of taking over the family farm. (From this point forward, all discussion of ordered probit model results will be assumed to be conditional on respondents having worked off the farm prior to entering farming.) Significant negative marginal effects of the age 65 or older group for the family takeover, additional income, and primary income reasons on outcome 3 (somewhat important or very important) as demonstrated in Table 4 suggest that older farmers were less likely to have entered farming for any of the three reasons. The marginal changes in the probabilities of farmers aged 65 or older responding somewhat or very important to these three reasons were $0.22,0.34$, and 0.30 lower, respectively, relative to the base age group younger than 35 . A plausible reason is that older farmers may have entered farming for other reasons. For example, Gillespie and Mishra (2011) found that entrants to cowcalf production were more likely to have been older and to have entered for reasons of living in a rural area or for outdoor activity.

Operators holding high school diplomas were more likely than nonholders to have entered farming for additional income or family takeover reasons. Furthermore, those with some college were more likely to have entered farming to take over the family farm. The strong relationship between high school and some college education with entering farming for family takeover reasons may reflect the previous generation's desire for the succeeding operator to have completed high school. The significant, positive coefficient for holding a graduate degree in entering farming as an additional income source likely reflects the higher opportunity costs associated with a graduate degree and the unwillingness of farmers with these degrees to terminate off-farm employment for farming. This is consistent with El-Osta, Mishra, and Morehart (2008), who found that operators with higher education were less likely to develop farming as a primary source of income as they had better chances of finding attractive off-farm jobs.

Race of the farm operator appears to play a role in explaining the reasons for entering farming after holding an off-farm job. White operators were less likely to have chosen farming for any of the three reasons, suggesting that reasons other than the three analyzed were more likely to have influenced their entry decisions. We have identified no previous research addressing the role of race in U.S. farmers' goal structures or reasons for entering farming, though Molnar and 
Dunkelberger (1981) addressed the role of race in college agricultural students' expectations of whether they would enter farming. They showed that white students were more likely to expect a career in farming, providing additional evidence of the role of race in farm entry decisions.

Results indicate that households including an elderly member (65 or older) were more likely to have entered farming for any of the three reasons. A plausible explanation is that elderly members of farm households desire to continue to be involved in farming with the help of the next generation. This result is consistent with Mishra, Raggi, and Viaggi (2010), who found that farms were less likely to exit if they had a family member who could take over the farming business. In cases where there were children under 17 years of age in the household, farmers were more likely to have entered farming for reasons of additional income or as a primary income source. The implication is that having children reinforces the goal of generating income relative to lifestyle goals, underscoring the importance of higher income with children in the household.

As expected, higher expected farm sales were positively related with having entered farming to develop a farm business as a primary source of income. The likelihood of having entered farming for any of the three reasons decreased if the farm was a sole proprietorship. A possible explanation is that farmers choose the ownership structure that maximizes the expected value of the farm, as discussed by Allen and Lueck (1998). As more people contribute to the asset base (i.e., via multiple owners or partnerships), it is plausible that a larger asset base would lead to higher financial performance. For example, in their study of successful U.S. dairy farms, Mishra and Morehart (2001) found a negative relationship between farm ownership as a sole proprietorship and returns to farming.

\subsection{Federal Farm Policy and Reasons for Choosing Farming as an Occupation}

In studying U.S. farm families, Mishra and El-Osta (2008) found that farm succession decisions were significantly influenced by government farm policy. Further, Key and Roberts (2006) found that agricultural support payments (government payments) had a significant impact on farm business survival. A possible explanation is that government payments increase returns and may also ease the liquidity constraint. Hubbard (1998) notes that firms with greater wealth (net worth) face lower borrowing costs because they have more resources from which they can secure loans and expand their firms. Government payments raise farm net worth through a positive impact on land values (Goodwin, Mishra, and Ortalo-Magné, 2003). This, in turn, contributes to farm viability and may be a driver to increased farm size.

Table 3 results show that farm operator households receiving loan deficiency payments (LDPs) were more likely to have entered farming for reasons of family 
takeover and developing the business as a primary income source. ${ }^{9}$ A plausible explanation could be the decoupled nature of these payments. In order to receive LDPs, farmers should be actively growing program crops. Furthermore, farm operator households receiving conservation reserve program (CRP) payments were more likely to have entered farming to take over the family farm. Again, in order to keep the payments coming to the farm family, farming activities should be practiced simultaneously on the farm. Furthermore, farm operator households receiving CRP payments were more likely to have entered farming to take over the family farm.

Marginal effects results (see Table 4, outcome 3) indicate that the probabilities of recipients of LDPs and CRP payments agreeing that they had entered farming for the family takeover reason were 18 and 10 percentage points higher, respectively, than for nonrecipients. Likewise, LDP recipients had increased probabilities of having entered farming as a primary income source that were 18 percentage points higher than for nonrecipients. These striking results are consistent with Mishra and El-Osta (2008). One can argue that the LDPs reduce financial insolvency and allow farms to remain in business, making farming more attractive to potential farm operators. Government payments perhaps serve as a means through which intergenerational transfer of a farm can result in a profitable business. A significant coefficient for "all other payments" suggests that the likelihood of entering farming for a primary income source increases with "all other payments," which include all government program payments besides LDPs, CRP payments, direct payments, and countercyclical payments. This result further supports the argument that government payments have a positive influence on farm entry for those wishing to farm for a primary income source. Among the three reasons for entering farming, the marginal probability differences for recipients of any of the government payments are relatively smaller for those choosing farming for an additional source of income, suggesting that recipients were less likely to have entered farming for an additional income source.

Table 5 provides predicted probabilities for five types of farm program payments-direct payments, countercyclical payments, LDPs, CRP payments, and all other payments-with regard to the three reasons for entering farming in later life. In each case, farm program payments were very or somewhat important when taking up farming. For example, the largest differences in the predicted probabilities associated with the participation status of the various types of

9 As one reviewer has noted, the decision to participate in this type of farm program and in the other types of farm programs considered in this study may be endogenous due to unobserved heterogeneity that may also work at impacting the reasons for entering farming conditional on off-farm employment decisions. This study can only presume, with a caveat, that this variable that denotes the type of farm program payments received, just like the other farm program participation variables, is exogenous particularly because of the added challenging aspect of dealing with the presence of, as in the case here, multiple potential endogenous variables when the outcome variable is nonlinear (see Vella, 1992). 
Table 5. Predicted Probabilities of the "Ordered Probit Sample-Selection" Models, 2004

\begin{tabular}{lll}
\hline \hline Take Over & Develop a Farm & Develop a Farm \\
Operation of the & Business as an & Business as a \\
Farm from a & Additional Source & Primary Source \\
Family Member & of Income & Income \\
\hline
\end{tabular}

Somewhat unimportant or not at all important

Household receiving direct payments:

$\begin{array}{llll}\text { Yes } & 0.2100 & 0.2484 & 0.1019 \\ \text { No } & 0.3966 & 0.2725 & 0.3083\end{array}$

Household receiving countercyclical payments:

$\begin{array}{lccc}\text { Yes } & 0.2168 & 0.2485 & 0.0943 \\ \text { No } & 0.3716 & 0.2713 & 0.2846 \\ \text { Household receiving LDPs: } & & \\ \text { Yes } & 0.1476 & 0.2643 & 0.0538 \\ \text { No } & 0.3869 & 0.2671 & 0.2925 \\ \text { Household receiving CRP payments: } & & \\ \text { Yes } & 0.2257 & 0.2717 & 0.2152 \\ \text { No } & 0.3547 & 0.2656 & 0.2493 \\ \text { Household receiving all other payments: } & & \\ \text { Yes } & 0.2743 & 0.2633 & 0.1026 \\ \text { No } & 0.3555 & 0.2673 & 0.2801\end{array}$

Neutral

Household receiving direct payments:

$\begin{array}{lccc}\text { Yes } & 0.1394 & 0.1743 & 0.1098 \\ \text { No } & 0.1494 & 0.1783 & 0.1868 \\ \text { Household receiving countercyclical payments: } & & \\ \text { Yes } & 0.1302 & 0.1736 & 0.1011 \\ \text { No } & 0.1470 & 0.1780 & 0.1795 \\ \text { Household receiving LDPs: } & & \\ \text { Yes } & 0.1173 & 0.1778 & 0.0809 \\ \text { No } & 0.1500 & 0.1769 & 0.1836\end{array}$

Household receiving CRP payments:

$\begin{array}{llll}\text { Yes } & 0.1304 & 0.1793 & 0.1520 \\ \text { No } & 0.1453 & 0.1768 & 0.1648\end{array}$

Household receiving all other payments:

$\begin{array}{llll}\text { Yes } & 0.1388 & 0.1754 & 0.1109 \\ \text { No } & 0.1447 & 0.1775 & 0.1761\end{array}$

Very or somewhat important

Household receiving direct payments:

$\begin{array}{llll}\text { Yes } & 0.6598 & 0.5772 & 0.7883 \\ \text { No } & 0.4541 & 0.5498 & 0.5049\end{array}$

Household receiving countercyclical payments:

$\begin{array}{lrcc}\text { Yes } & 0.6529 & 0.5779 & 0.8044 \\ \text { No } & 0.4814 & 0.5502 & 0.5359 \\ \text { Household receiving LDPs: } & & \\ \text { Yes } & 0.7351 & 0.5578 & 0.8635 \\ \text { No } & 0.4631 & 0.5560 & 0.5238 \\ \text { Household receiving CRP payments: } & & \\ \text { Yes } & 0.6439 & 0.5489 & 0.6328 \\ \text { No } & 0.5000 & 0.5573 & 0.5859\end{array}$


Table 5. Continued

\begin{tabular}{cccc}
\hline \hline & $\begin{array}{l}\text { Take Over } \\
\text { Operation of the } \\
\text { Farm from a } \\
\text { Family Member }\end{array}$ & $\begin{array}{l}\text { Develop a Farm } \\
\text { Business as an } \\
\text { Additional Source } \\
\text { of Income }\end{array}$ & $\begin{array}{l}\text { Develop a Farm } \\
\text { Business as a } \\
\text { Primary Source } \\
\text { of Income }\end{array}$ \\
\hline $\begin{array}{c}\text { Household receiving all other payments: } \\
\text { Yes }\end{array}$ & 0.5869 & 0.5613 & 0.7866 \\
No & 0.4998 & 0.5551 & 0.5438 \\
\hline \hline
\end{tabular}

Notes: Sum of predicted probabilities of the outcomes for each type of government program participation of each of the three ordered probit sample-selection models may not add up to 1 due to rounding. CRP, conservation reserve program; LDP, loan deficiency payment.

Source: Authors' calculations.

government payments are seen for farmers having entered farming as a primary source of income. Predicted probabilities of 0.86 for LDP recipients versus 0.52 for nonrecipients, 0.63 versus 0.58 for CRP payments, and 0.79 versus 0.54 for "all other payments" suggest an overall positive effect of government policy payments on the likelihood of choosing farming as a primary source of income, ceteris paribus. A higher positive prediction for CRP recipients than nonrecipients further suggests a positive effect of this policy in choosing farming for the family takeover reason. Individuals who choose to enter farming for a primary source of income, on the other hand, may need to invest in their farms to increase the size and scope of their farming operations. These farmers would, thus, care more about LDPs and "all other payments" relative to CRP payments.

\section{Summary and Conclusions}

A phenomenon that has been observed in recent years is that many entrants in the farming sector used to work off the farm before becoming farmers. There might be several reasons for entering farming as an occupation in later life, including farm program payments. It is plausible that for many who are retiring from nonfarm jobs, the potential for government payments allows these producers the possibility of entering an occupation they desire, farming. First, using individual farm-level data, this study investigated the factors affecting an individual's decision to become a farmer after or while holding off-farm employment. Second, conditional on having worked off the farm during or before entering farming, the study investigated the degree of importance of becoming a farmer as it relates to the following: (1) taking over the operation of the farm from a family member, (2) developing a farm business as an additional source of income, and (3) developing a farm business as a primary source of income.

In terms of reasons for off-farm workers to decide to enter farming, age matters. Older farmers were less likely to have entered farming after or while working off the farm for reasons of taking over the family farm, additional income, or as a primary income source. This implies that they entered for other 
reasons, perhaps those related to lifestyle or a "retirement job." In addition, more highly educated farmers were more likely to have worked in a current or a previous off-farm job prior to farming. Of those farm operators with a current or a previous off-farm job, those with graduate degrees were more likely to have done so for additional income rather than as a primary income source, underscoring the importance of the greater opportunity costs to farming associated with higher education. Also apparent is that those who fully owned all of their acreage were less likely to have entered farming for family takeover or primary income source reasons. From these results, there emerges a farm segment of older and, in many cases, highly educated operators who have accumulated enough wealth to purchase farmland outright and farm for lifestyle reasons and/or additional income in retirement. Casual observation in many rural communities reveals the existence of a substantial population of individuals of this segment.

Another observation of note from examining demographic results is that operators with older household members were more likely to have entered for each of the three reasons. This suggests several things. First, on a substantial proportion of the farms, takeover of the farm by the previous generation occurs after the operator has worked off the farm, presumably in many cases for a significant time period. This is likely partially reflective of the career longevity of farmers, who often retire at advanced age and may not be ready to "turn over the reins" of the farm to the next generation until then. It may also reflect the need of young potential farmers to accrue substantial wealth from off-farm sources before entering farming, even in cases where they are taking over operation of the farm from a family member. Finally, the presence of an older generation in the household may suggest continued involvement of the previous generation on the farm, even if major farm decisions are being made by the subsequent generation.

One of the most significant findings of this study suggests that transfer payments from the government, in the form of farm program payments (LDPs, CRP payments, and "all other payments") may be providing significant incentives to retired off-farm workers to take up farming as an occupation in later life. For example, households receiving LDPs were more likely to have entered farming for the family takeover and primary income source reasons. On the other hand, households receiving CRP payments were more likely to have become farmers for purposes of taking over the family farm. These farm payments may be signaling an incentive that is fueling some individuals to become farmers in later life, though the reasons for taking up farming in later life may differ. Hence, this study may provide insights to policy makers in designing policies that will attract workers back to the farm and foster rural development.

This being the first study we are aware of to delve into the dynamics of off-farm work prior to entering farming, we naturally can raise a number of questions that deserve further research. One question that our data do not allow us to examine is why some individuals with previous off-farm work experience 
do not opt to enter farming-comparing the motivations of that population with the population that does enter farming. This is a subject that would be of interest for future studies with other data sets. Perhaps of greatest interest would be to examine the length of time an individual works off the farm prior to farming; some will have worked off the farm for only a few years to accumulate enough wealth to enter farming, whereas others begin farming for retirement activity/income. Further examination of the dynamics of this phenomenon as it relates to farm demographics could have substantial policy implications, particularly in developing programs targeting young and beginning farmers.

\section{References}

Ahearn, M.C., H. El-Osta, and J. Dewbre. "The Impact of Coupled and Decoupled Government Subsidies on Off-Farm Labor Participation of U.S. Farm Operators.” American Journal of Agricultural Economics 88,2(2006):393-408.

Ahearn, M.C., J.E. Perry, and H.S. El-Osta. The Economic Well-Being of Farm Operator Households, 1988-90. Washington, DC: U.S. Department of Agriculture, Economic Research Service, Agricultural Economic Report No. 666, 1993.

Ahituv, A., and A. Kimhi. "Off-Farm Work and Capital Accumulation Decisions of Farmers over the Life-Cycle: The Role of Heterogeneity and State Dependence." Journal of Development Economics 68,2(2002):329-53.

Allen, D.W., and D. Lueck. "The Nature of the Farm." Journal of Law and Economics 41,2(1998):343-86.

Barkley, A.P. "The Determinants of the Migration of Labor out of Agriculture in the United States, 1940-85." American Journal of Agricultural Economics 72,3(1990):567-73.

Becker, G.S. Human Capital: A Theoretical and Empirical Analysis, with Special Reference to Education. New York: Columbia University Press, 1964.

Boskin, M.J. “A Conditional Logit Model of Occupational Choice.” Journal of Political Economy 82,2(1974, pt. 1):389-98.

Breustedt, G., and T. Glauben. "Driving Forces behind Exiting from Farming in Western Europe." Journal of Agricultural Economics 58,1(2007):115-27.

Burchinal, L.G. "Differences in Educational and Occupational Aspirations of Farm, SmallTown, and City Boys.” Rural Sociology 26,2(1961):107-21.

D’Antoni, J.M., A.K. Mishra, and A.P. Barkley. "Feast or Flee: Government Payments and Labor Migration from U.S. Agriculture.” Journal of Policy Modeling 34,2(2012):18192.

De Luca, G., and V. Perotti. "Estimation of Ordered Response Models with Sample Selection." Stata Journal 11,2(2011):213-39.

Duncan, C.S., A.J. Khattak, and F.M. Council. "Applying the Ordered Probit Model to Injury Severity in Truck-Passenger Car Rear-End Collisions." Transportation Research Record 1635(1998):63-71.

Edwards, C., and T. DeHaven. "Farm Subsidies at Record Levels as Congress Considers New Farm Bill.” Cato Institute Briefing Papers, No. 70, Washington, DC: Cato Institute, 2001.

El-Osta, H.S., A.K. Mishra, and M.C. Ahearn. "Labor Supply by Farm Operators under 'Decoupled' Farm Program Payments." Review of Economics of the Household 2,4(2004):367-85. 
El-Osta, H.S., A.K. Mishra, and M.J. Morehart. "Off-Farm Labor Participation Decisions of Married Farm Couples and the Role of Government Payments.” Review of Agricultural Economics 30,2(2008):311-32.

Foltz, J.D. "Entry, Exit, and Farm Size: Assessing an Experiment in Dairy Price Policy." American Journal of Agricultural Economics 86,3(2004):594-604.

Ford, J., and S. Box. "Sociological Theory and Occupational Choice." Sociological Review 15,3(1967):287-99.

Gasson, R. "The Choice of Farming as an Occupation." Sociologia Ruralis 9,2(1969):146-66. . "Occupations Chosen by the Sons of Farmers." Journal of Agricultural Economics 19,3(1968):317-26.

Gillespie, J., and A. Mishra. "Off-Farm Employment and Reasons for Entering Farming as Determinants of Production Enterprise Selection in U.S. Agriculture." Australian Journal of Agricultural and Resource Economics 55,3(2011):411-28.

Ginzberg, E., S.W. Ginsburg, S. Axelrad, and J.L. Herma. Occupational Choice: An Approach to a General Theory. New York: Columbia University Press, 1966.

Glauben, T., H. Tietje, and C.R. Weiss. "Intergenerational Succession in Farm Households: Evidence from Upper Austria." Review of Economics of the Households 2,4(2004):44361.

Goodwin, B.K., A.M. Featherstone, and K. Zeuli, "Producer Experience, Learning by Doing, and Yield Performance." American Journal of Agricultural Economics 84,3(2002):66078 .

Goodwin, B.K., and A.K. Mishra. "Farming Efficiency and the Determinants of Multiple Job Holding by Farm Operators." American Journal of Agricultural Economics 86,3(2004):722-29.

Goodwin, B.K., A.K. Mishra, and F.N. Ortalo-Magné. "What's Wrong with Our Models of Agricultural Land Values." American Journal of Agricultural Economics $85,3(2003): 744-52$.

Greene, W.H. Econometric Analysis. 6th ed. Upper Saddle River, NJ: Pearson/Prentice-Hall, 2008.

Haller, A.O., and W.H. Sewell. "Occupational Choices of Wisconsin Farm Boys.” Rural Sociology 32,1(1967):37-55.

Hubbard, R.G. "Capital-Market Imperfections and Investment." Journal of Economic Literature 36,1(1998):193-225.

Key, N., and M.J. Roberts. "Government Payments and Farm Business Survival." American Journal of Agricultural Economics 88,2(2006):382-92.

— . "Nonpecuniary Benefits to Farming: Implications for Supply Response to Decoupled Payments." American Journal of Agricultural Economics 91,1(2009):1-18.

Kimhi, A. "Is Part-Time Farming Really a Step in the Way out of Agriculture?" American Journal of Agricultural Economics 82,1(2000):38-48.

Kimhi, A., and R. Bollman. "Family Farm Dynamics in Canada and Israel: The Case of Farm Exits." Agricultural Economics 21,1(1999):69-79.

Kimhi, A., and N. Nachlieli. "Intergenerational Succession on Israeli Family Farms.” Journal of Agricultural Economics 52,2(2001):42-58.

Laband, D.N., and B.F. Lentz. "Occupational Inheritance in Agriculture." American Journal of Agricultural Economics 65,2(1983):311-14.

Lucas, R.E.B. "Hedonic Wage Equations and Psychic Wages in the Returns to Schooling." American Economic Review 67,4(1977):549-58.

Mishra, A.K., and H.S. El-Osta. "Effect of Agricultural Policy on Succession Decisions of Farm Households." Review of Economics of the Household 6,3(2008):285-307. 
Mishra, A.K., H.S. El-Osta, M.J. Morehart, J.D. Johnson, and J.W. Hopkins. Income, Wealth, and the Economic Well-Being of Farm Households. Washington, DC: U.S. Department of Agriculture, Economic Research Service, Agricultural Economic Report No. 812, 2002 .

Mishra, A.K., H.S. El-Osta, and S. Shaik. "Succession Decisions in U.S. Family Farm Businesses." Journal of Agricultural and Resource Economics 35,1(2010):133-52.

Mishra, A.K., J.M. Fannin, and H. Joo. "Off-Farm Work, Intensity of Government Payments, and Farm Exits: Evidence from a National Survey in the United States." Canadian Journal of Agricultural Economics 62,2(2014):283-306.

Mishra, A.K., and M.J. Morehart. "Factors Affecting Returns to Labor and Management on U.S. Dairy Farms.” Agricultural Finance Review 61,2(2001):123-40.

Mishra, A.K., M. Raggi, and D. Viaggi. "Determinants of Farm Exit: A Comparison between Europe and United States." Paper presented at the European Association of Agricultural Economists 114th Seminar, Berlin, Germany, April 15-16, 2010.

Molnar, J.J., and J.E. Dunkelberger. "The Expectation to Farm: An Interaction of Background and Experience." Rural Sociology 46(1981):62-84.

Pietola, K., M. Väre, and A.O. Lansink. "Timing and Type of Exit from Farming: Farmers' Early Retirement Programmes in Finland.” European Review of Agricultural Economics 30,1(2003):99-116.

Portes, A., A.O. Haller, and W.H. Sewell. "Professional-Executive vs. Farming as Unique Occupational Choices.” Rural Sociology 33,2(1968):153-59.

Rahelizatovo, N.C., and J.M. Gillespie. "Dairy Farm Size, Entry, and Exit in a Declining Production Region.” Journal of Agricultural and Applied Economics 31,2(1999):33347.

Schmidt, P., and R.P. Strauss. "The Prediction of Occupation Using Multiple Logit Models." International Economic Review 16,2(1975):471-86.

Serra, T., B.K. Goodwin, and A.M. Featherstone. "Agricultural Policy Reform and Off-Farm Labour Decisions." Journal of Agricultural Economics 56,2(2005):271-85.

Theil, H. Principles of Econometrics. New York: John Wiley and Sons, 1971.

U.S. Department of Agriculture. Internet site: http://www.usda.gov/wps/portal/usdahome (Accessed December 12, 2011).

U.S. Department of Agriculture, Economic Research Service. "Agricultural Resource Management Survey (ARMS) Briefing Room.” Internet site: http://www.ers.usda.gov/ Briefing/ARMS (Accessed December 2, 2011a).

- "County Typology Codes.” Internet site: http://www.ers.usda.gov/data-products/ county-typology-codes/documentation.aspx (Accessed December 2, 2011b).

U.S. Department of Commerce, U.S. Census Bureau. "Current Population Survey (CPS)." Internet site: http://www.census.gov/programs-surveys/cps.html (Accessed December 20, 2011).

Vella, F. "Simple Tests for Sample Selection Bias in Censored and Discrete Choice Models." Journal of Applied Econometrics 7,4(1992):413-21.

Weiss, C.R. "Farm Growth and Survival: Econometric Evidence for Individual Farms in Upper Austria." American Journal of Agricultural Economics 81,1(1999):103-16.

Zepeda, L. "Asymmetry and Nonstationarity in the Farm Size Distribution of Wisconsin Milk Producers: An Aggregate Analysis.” American Journal of Agricultural Economics 77,4(1995):837-52. 